\title{
What is an Award Worth? An Econometric Assessment of the Impact of Awards on Employee Performance
}

\author{
SUSANNE NECKERMANN \\ RETO CUENI \\ BRUNO S. FREY
}

CESIFO WORKING PAPER NO. 2657

CATEGORY 4: LABOUR MARKETS

MAY 2009

\footnotetext{
An electronic version of the paper may be downloaded

- from the SSRN website: www.SSRN.com

- from the RePEc website: - from the CESifo website: 


\title{
What is an Award Worth? An Econometric Assessment of the Impact of Awards on Employee Performance
}

\begin{abstract}
Behavioral economics documents the importance of status and self-image concerns in the workplace, but is largely silent about how to instrumentalize them to induce effort. Awards widespread in the corporate sector and elsewhere - are motivators that derive their value from such social concerns. Panel data from the call center of a large international bank allow us to estimate the impact of receiving an award on effort. The performance of winners proves to be significantly higher than that of comparable non-recipients after the award has been presented. This increase in work effort is sizeable, robust, and not driven by reverse causation.
\end{abstract}

JEL Code: C23, J33, M52.

Keywords: awards, motivation, non-monetary compensation, event-study, incentives.

\author{
Susanne Neckermann \\ University of Zurich \\ Switzerland - Zurich \\ sneckermann@iew.uzh.ch
}

\author{
Reto Cueni \\ University of Zurich \\ Switzerland - Zurich \\ rcueni@iew.uzh.ch
}

Bruno S. Frey

University of Zurich

Switzerland - Zurich

bsfrey@iew.uzh.ch

For helpful suggestions we are indebted to Drazen Prelec, Ernst Fehr, Michael Jensen, Charles Efferson, Florian Peters, Lorenz Götte, Stephan Meier, Felix Oberholzer-Gee, Alois Stutzer, Christine Benesch, Simon Lüchinger, Alexander Wagner, Nadia Schweizer, and Gabriele Nardo. We also thank the participants of the various seminars and conferences where this paper was presented for their feedback. 
"If an organization is going to function well, it should not rely solely on monetary compensation schemes."

Akerlof and Kranton (2005)

\section{Introduction}

Awards are increasingly popular in the corporate sector, where managers consider innovative human resource practices, such as awards, to be essential for firm competitiveness (Ichniowski and Shaw 2003). In his book 1001 Ways to Reward Employees, Nelson (2005) provides ample evidence of the number and variety of awards in companies. The prevalence and popularity of awards in the corporate sector suggest that awards fulfill important functions in principal-agent relationships. However, to date there is no clear empirical evidence on the effect of these kinds of social incentives on performance.

Using an event study technique that exploits the matched nature of our panel data, we are able to causally identify the effect of receiving an award on subsequent employee performance in the call center of a large international bank. Specifically, the data set is unique

in that the awards studied are directed towards valuable activities such as substituting for colleagues or making improvement suggestions, which are uncorrelated with the performance measured in the call center. This feature ensures the exogeneity of the intervention. We find that award winners substantially increase their subsequent performance relative to both nonrecipients and their own previous performance. This result is robust to alternative specifications that check the validity of the identifying assumption and the specifics of the econometric technique used. Hence, the receipt of an award enhances performance even inf job dimensions that are not incentivized with the award. The documented ex-post performance enhancement adds to the presumably positive impact on the rewarded activity itself and the incentive effect of the award system per se, and it suggests that awards are valuable incentive instruments that should be taken seriously as additional instruments in 
principal-agent relationships.

How do these predominantly nonmonetary, reputation-based rewards fit into the economic literature where they have been basically ignored to date? Previously, when economists studied incentives in organizations, the focus was on monetary payments in exchange for performance on specific, measurable dimensions. This is illustrated by the large literature on incentive pay to align the interests of principal and agent starting with the pioneering works by Alchian and Demsetz (1972) and Jensen and Meckling (1976). In recent years, works in behavioral economics have explored a wider set of motivations in the workplace such as status (Auriol and Renault 2008), concerns for social recognition (Brennan and Pettit 2004) and positive self-image (Bénabou and Tirole 2002), feedback (Suvorov and van de Ven 2006), and identity (Akerlof and Kranton 2005). However, this literature has largely been silent about how these social concerns can be instrumentalized to induce effort in a systematic and predictable way.

Awards are a widely used means of motivating workers in organizations and we argue that they derive their value from these kinds of social concerns. In award schemes, an agent is given a symbolic reward for good performance in combination with positive performance feedback and social recognition from superiors and peers. The value of an award depends on its scarcity as a positional good as well as on the usefulness of the performance feedback and the appreciation of the recognition. While there is no universally accepted definition of awards, essential elements are (1) the publicity of the winners, (2) a set of deliberately vague evaluation criteria, (3) the unenforceability of awards, and (4) their tournament character. Although awards contain features of other motivators, such as performance bonuses, pure feedback, gifts, and praise, they can be clearly distinguished from them.

We are aware of only a few other papers that explicitly study awards. Hansen and Weisbrod (1972) and Frey (2005) address awards as incentives in general. Markham, Scott, 
and McKee (2002) show in a quasi-experimental setting that the introduction of a public recognition program to reduce absenteeism decreases the latter by 52 percent. Gavrila et al. (2005) describe the optimal solution for the management of awards over time, considering that their incentive effect depends on the number of awards that are presented. Besley and Ghatak (2008) analyze a principal-agent setting with social incentives, such as job titles or awards. The decisive feature of these rewards is that they have zero marginal costs, so it is incentive compatible for the principal to award them even if the payoff is not verifiable. Elsewhere, we show that awards act as incentives, significantly influencing performance before they are presented (Neckermann and Frey 2008; Neckermann and Kosfeld 2008). Malmendier and Tate (2008) also show how the receipt of a title, like "CEO of the Year," affects subsequent performance. However, their paper is concerned with extra-organizational awards that are exogenous to the principal-agent relationship of interest. These kinds of awards differ in essential ways from intra-organizational awards. They are presented by a person or institution that is not the principal of the agent whose performance is affected, for a different set of reasons, and they come with a different set of benefits for the recipient. Therefore, their findings cannot be generalized to intra-organizational awards.

This paper contributes to the discussion of rewards by presenting the first empirical evidence on the effect of receiving these kinds of social incentives on performance. This suggests that the traditional focus on monetary incentives is too narrow because other motivators, tapped by instruments such as awards, have a significant and systematic effect on employee performance. Further, we show that such rewards have an independent positive effect on behavior after they are awarded; hence, it is not sufficient to consider only the ex-ante incentive effect of rewards, that is, while employees work towards receiving them. The significant behavioral effect of these social incentives also fits well into the current discussion on the disparity between the impact of monetary incentives in the lab and in 
the field. While lab studies find a large behavioral effect of wage increases, effort reacts relatively little in the field. Some authors (see, e.g., Dur [2008]) argue that this divergence is caused by the fact that employers in the field typically use motivators other than wages, for example, recognition, to signal kind intentions. Therefore, employees do not reciprocate to wage increases in the field to the extent they do in the lab, where money is the only means of signaling kind intentions.

Section II presents the data and the estimation technique. In Section III, the empirical findings are discussed and Section IV concludes.

\section{Data}

The data set comprises information on awards as well as the employee performance of the 155 call center agents of a credit card service company of a large international bank and covers the period from January 2004 to October 2007. The call center is responsible for handling customer complaints and questions and consists of six work groups, each with one group manager. Management considers the call center of key importance for the company's success because it represents an important interface between the company and its customers.

\subsection{Dependent Variable: Performance}

The company records daily performance for a number of different performance dimensions, starting in the second month of employment to allow for initial learning. On a monthly and yearly basis, these measures are transformed into rankings and aggregated into a single performance index. In particular, for each dimension, the percentage deviation between individual performance and the average monthly performance of all the call center agents is calculated and changed into a rating between 5 (very good) and 1 (unsatisfactory), 
according to a matrix set up by the department head. As an example, an agent that performs 120 percent of the average performance in a dimension receives a rating of 5 in that dimension, and an agent whose performance is 80 percent or lower receives a rating of 1 . The relative nature of the performance measurement is an advantage for our study because it ensures that all time-varying, exogenous factors that affect the absolute performance of all call center agents are excluded. ${ }^{1}$ Specifically, the measurement is not affected by an increase in the number or difficulty of calls or by improvements in the technical infrastructure. Both of these factors render absolute performance incomparable over time. In line with exerted effort, the relative rating further ensures that a certain number of calls answered translates into a higher rating in slow rather than in busy months. We basically use the same index as the company to ensure that our performance measure corresponds to the company's assessment of good and bad performance. Because the company continually refines the exact calculation of its performance index by adding and removing different performance dimensions from it, a core performance measure was constructed in collaboration with the call center manager. Our performance index comprises the following six dimensions that have been part of the company's index in all of the periods covered: ${ }^{2}$

1. Calls Taken Per Hour: Average number of phone calls handled per hour.

\footnotetext{
${ }^{1}$ Theoretically, relative performance measures may have the downside that a change in ratings may not always reflect corresponding changes in effort; hence, ratings may not be comparable across months. This is the case when a variation in the average absolute performance causes a given effort to translate into different ratings in different months. In our setting, however, absolute performance does not exhibit a systematic trend and typically changes only very little between two months in all dimensions. Moreover, the nature of the task renders it highly unlikely that employee fluctuation causes changes in ability distributions dramatic enough to have a sizeable impact on absolute performance. Therefore, any change in absolute performance that we observe likely reflects changes in working conditions that should be filtered out.

${ }^{2}$ The company's changes in the index do not reflect systematic and sustained improvements of performance evaluation, which would have suggested that we should use the changing index too. Rather all dimensions that are not captured in our core rating were added and removed at various instances. Examples are the two dimensions Training, which measures an employee's performance in in-house training courses, and Write off Policy, which measures the degree to which employees follow company guidelines on goodwill issues. Both dimensions were in the company's index only in 2006.
} 
2. Call Handling Time: Average length of phone call.

3. After Call Worktime: Average amount of time needed to process the request after the call has been ended.

4. Transfer Rate: The average ratio between calls handled by the employee and the number of phone calls that were transferred to colleagues or other service units.

5. Lates: Number of days on which the employee showed up late for work.

6. Quality: Quality of client handling as assessed by supervisors and clients. ${ }^{3}$

Of these dimensions, only the dimension Lates is not evaluated relatively, but according to an absolute scale (no absence corresponds to a rating of 4 , one absence to a rating of 3 , and more than one absence to a rating of 1 ). The resulting six ratings are then combined to a single overall rating according to the same weighting scheme used by the company. ${ }^{4}$ Specifically, Quality enters with a weight of 50 percent and the five other dimensions with 10 percent each. The weighting scheme suggests that the company places equal emphasis on technical measures, such as the number and durations of calls, and content measures, which capture the actual interaction between employee and customer. The resulting index provides a global, overall assessment of performance. It captures all the relevant trade-offs the company faces, ensuring that employees do not improve their rating, for instance, by answering more calls at the expense of call quality. The management confirmed that our

\footnotetext{
${ }^{3}$ The rating has an internal and an external component, each of which accounts for 50 percent of the quality rating. Internal quality is assessed by the group manager by periodically monitoring the conversations of each agent. The assessment follows a clear set of rules and guidelines that leave virtually no room for subjectivity and thereby ensure the objectivity of the measure. Evaluation criteria are, for example, whether the agent correctly introduces herself and asks the right set of questions in the prescribed order. The external quality rating is generated by an outside company that conducts surveys with the company's customers.

${ }^{4}$ The addition and deletion of performance dimensions in the company's indices in different years were accompanied by changes in the weights of the individual dimensions. However, the relative weights of the six core performance dimensions remained basically identical throughout the entire time period covered.
} 
core index captured overall performance well and that no important performance dimension was neglected. Figure 1 exhibits the density of performance ratings.

Figure 1: Distribution of Performance Ratings Against a Normal Distribution

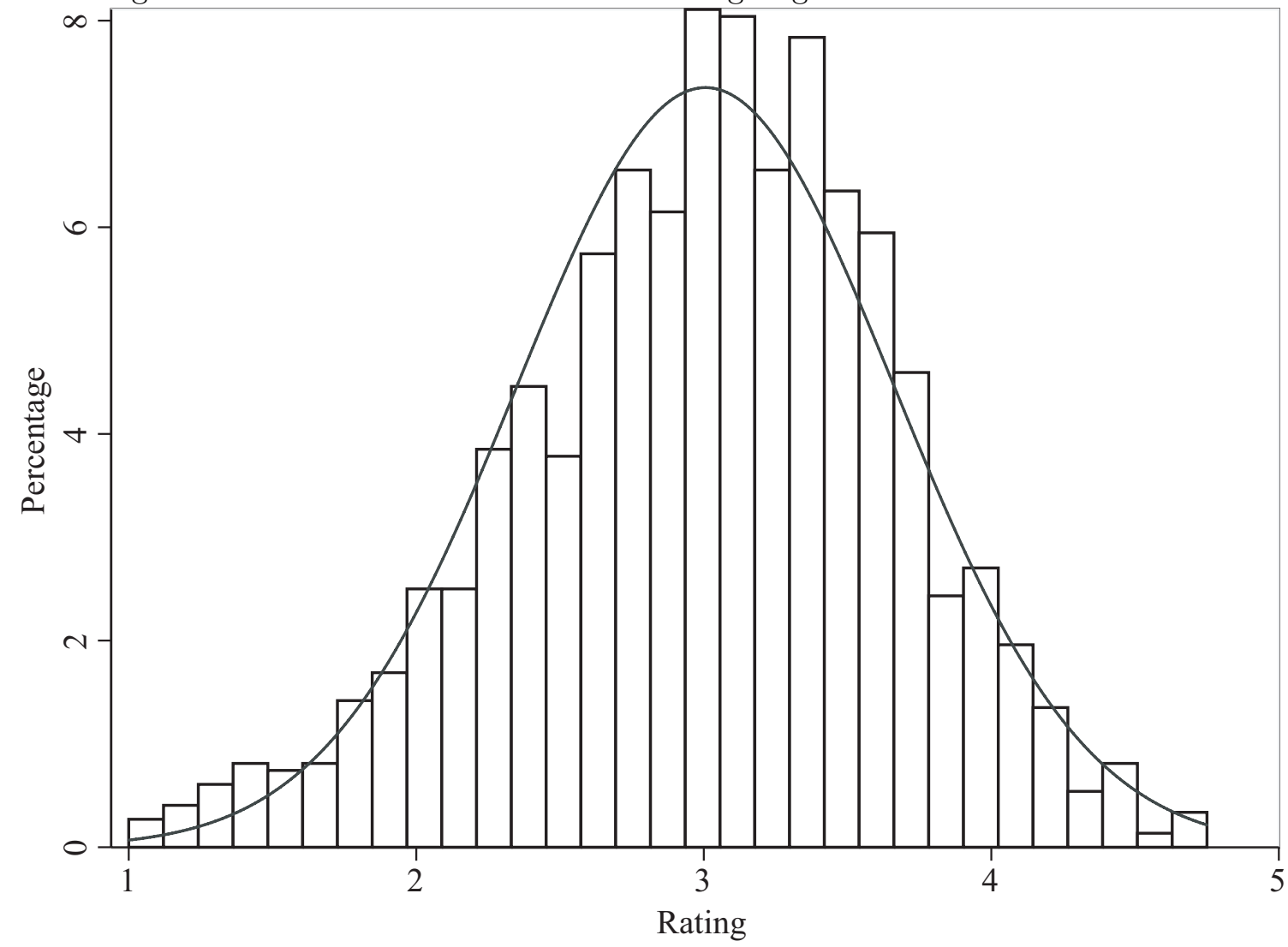

The performance ratings are approximately normally distributed with an average of 3.02 and a standard deviation of 0.66 and do not exhibit a time trend. The mean and variation corroborate the objective, quantitative nature of our performance data, as subjectively determined evaluation data typically cluster around high values (on the leniency bias see, e.g., Murphy and Cleveland [1995]; Yariv [2006]) and may cause endogeneity problems because managers might assess award-receiving individuals more favorably. The resulting 
index represents a weighted average of quantitative performance measures. Thus, we can treat the rating as cardinal because it takes on many different values and does not have the quality of an ordinal grading scheme.

\subsection{Independent Variables: Awards}

The company has a variety of awards. These are called the Thank You Reward, the Gold Reward, the Platinum Reward, the President Reward, Employee of the Month, and Employee of the Year. The requirements for qualifying for these awards increase from Thank You Reward to Employee of the Year. While a Thank You Reward, an email notification and a letter sent to the employee's home address, allows a spontaneous exchange of thanks among colleagues, the President Reward remunerates activities that have benefited the company as a whole; these require approval by the CEO and come with a personal congratulation by the department head. The winners of Employee of the Month and Employee of the Year are selected by a reward committee and the CEO from among the winners of the Platinum and President Rewards. For all awards, there is a close connection between effort and likelihood of nomination, so that individuals can actively pursue winning an award. Appendix A. contains a full description of the awards, their requirements, approval procedures, and associated benefits. The award program of the company has been in place since 2001. Therefore, we cannot estimate how the presence of the award system per se changes performance because there is no control group without awards. Rather, this ex-ante incentive effect of awards is part of the baseline motivation of each employee and constant throughout the period of our study. ${ }^{5}$

While our data set contains information on the winners of all awards other than the Thank you Reward, only the Gold Reward lends itself to a statistical examination be-

\footnotetext{
${ }^{5}$ This incentive effect potentially changes with winning an award. One might argue that the motivation to win decreases once an award has been won. However, such a potential change in baseline motivation renders the detection of a positive change in performance caused by the receipt of an award more difficult.
} 
cause there are too few observations of call center agents winning the other, more prestigious awards. The Gold Reward remunerates exceptional efforts that benefit the entire work group. Nominations can be made by colleagues as well as supervisors. ${ }^{6}$ An award is presented by the call center manager in front of the worker's colleagues in the middle of the following month. Award winners, as well as their colleagues, only learn about the award then. There is no additional announcement of the award winners; however, the management takes care to present the award when many colleagues are on hand, that is, the entire call center as all call center agents work in one big office. The award is accompanied by a certificate for the wall, which serves as a reminder and ensures that agents not present when the award is presented learn about it, as well as a symbolic bonus of around Swiss Franc (CHF) 150. Examples of behaviors that qualify for a Gold Reward are volunteering as a substitute during vacation times, initiating and implementing team events, making improvement suggestions, and helping others with good advice. Importantly, awards are not presented for the performance used as the dependent variable in our analysis. In fact, core performance is uncorrelated with the activities that lead to an award. Awards are therefore exogenous, and their causal effect on core performance can be identified by comparing the performance of winners and nonrecipients subsequent to winning. If awards depended on performance, they would always be - at least, in part - a reflection of good performance, and a careful creation of control groups would be necessary to identify the causal effect.

The data set comprises 46 awards (Gold Reward January 2004 to Gold Reward October 2007). Overall, 158 Gold Rewards were presented to the 155 call center agents between 2004 and 2007. As expected, the distribution is skewed to the right. Two agents received

\footnotetext{
${ }^{6}$ About half of the nominations come from group supervisors and the other half from colleagues. The reasons provided for the nominations do not differ systematically between those by supervisors and colleagues. The Human Resources Department communicates the criteria for nominations well, so almost all nominations result in an award. Interviews with group managers and employees further suggest that employees deserving an award are not ignored, especially as so many individuals can nominate.
} 
a total of eight Gold Rewards, whereas 76 got none. ${ }^{7}$ These numbers suggest that the award is sufficiently scarce for it to be valuable to its recipients, and the sample is well balanced between winners and nonrecipients because about half of the agents never received an award. On average, 3.4 awards are presented per month with a minimum of zero and a maximum of 11 .

\subsection{Further Data Information}

The data set comprises a total of 1480 id-month observations. ${ }^{8}$ Sixty-three percent of the agents in the sample are female, and the agents remain in the sample for 18 months on average.

The call center agents are paid a fixed monthly wage of CHF 4,500 (about \$4,500). The exact sum the individual receives depends on her level of experience, knowledge of languages, and length of employment at the call center. The Gold Reward complements the company's salary scheme because it incentivizes activities such as substituting for colleagues or organizing team events that are not remunerated as part of the fixed wage. The management asserted that receiving a Gold Reward had no effect on future promotion decisions and award winners did not receive special attention, training, or other advantages, for which we cannot control. Hence, while in-house training presents a positive shock to productivity, it is not correlated with winning awards; therefore, it does not cause systematic biases because they are not correlated with winning an award.

\footnotetext{
${ }^{7}$ Figure 3 in the Appendix shows the entire frequency distribution of the number of Gold Rewards per employee.

${ }^{8}$ The initial data set comprised some additional id-month observations that were lost because one or more performance dimensions were not recorded in a particular month due to vacation, sick leave, or failure of the manager to assess the dimension Quality.
} 


\section{Awards and Performance}

\subsection{Empirical Specification}

To obtain an unbiased estimate of the effect of awards on subsequent performance, one needs a control group of individuals that is identical to those in the treatment group (the group of award winners) in all relevant observable and unobservable factors. Then, the performance of individuals in the control group provides a valid counterfactual for the performance of award winners, and the effect of an award can be estimated as the average difference in performance between individuals in the two groups. Typically, control groups are constructed ex-post via matching procedures (see Angrist and Krueger [1999] for an overview). In our particular case, a Gold Reward is directed towards behaviors such as supporting colleagues and organizing team events that are not captured in the core performance rating. This unique feature of our data set suggests that there is no difference in the core performance of award winners and nonrecipients prior to the award. Therefore, we can make the identifying assumption that award winners and nonrecipients of the Gold Reward are homogeneous in all factors - other than a fixed effect that we estimate for each individual - that drive core performance prior to winning an award. The quality of this matching (i.e., the validity of our identifying assumption) will be tested as part of the analysis below.

Therefore, to estimate the effect of receiving an award on subsequent performance, we use an event study technique that allows us to estimate period-specific effects both before and after a Gold Reward is won. ${ }^{9}$

The following table presents an overview over the three dimensions used to identify and quantify the effect of a Gold Reward on employee performance:

\footnotetext{
${ }^{9}$ A similar technique to study period-specific effects of events was used, for instance, by Greenstone and Moretti (2003) and Peters and Wagner (2008). Event studies have a long history in economics and are used in a variety of settings. An overview is presented in MacKinlay (1997).
} 
Table 1: Dimensions of Identification Strategy

\begin{tabular}{|c|c|c|}
\hline Dimension & Value & Use \\
\hline Time relative to event & $\begin{array}{l}\text { Before bestowal of Gold Reward } \\
\text { vs. after bestowal of Gold Reward }\end{array}$ & $\begin{array}{l}\text { Allows testing the homogeneity of } \\
\text { winners and nonrecipients with respect } \\
\text { to core performance prior to the } \\
\text { bestowal of a Gold Reward. }\end{array}$ \\
\hline Type of performance & $\begin{array}{l}\text { Core Performance vs. behaviors } \\
\text { that qualify for a Gold Reward }\end{array}$ & $\begin{array}{l}\text { Ensures exogeneity of event (Gold } \\
\text { Reward) on core performance } \\
\text { (dependent variable). }\end{array}$ \\
\hline Treatment & $\begin{array}{l}\text { Winner of Gold Reward vs. } \\
\text { nonrecipient }\end{array}$ & $\begin{array}{l}\text { Identification of the size of the effect of } \\
\text { a Gold Reward on core performance. }\end{array}$ \\
\hline
\end{tabular}

Under the identification strategy presented above, the causal effect of receiving an award on employee performance is estimated by fitting the following equation:

$$
Y_{i t}=\alpha+\sum_{\tau=\underline{T}}^{\bar{T}} \pi_{\tau} W_{i \tau}+\mu_{i}+\beta X_{i t}+\xi_{i t} .
$$

The dependent variable $Y_{i t}$ represents the performance rating of employee $i$ in period $t$. Because $Y_{i t}$ is constructed as the weighted average of the ratings in the individual performance dimensions discussed above, it takes on many different values and can be treated as continuous (see, e.g., Wooldridge [2002], p. 533). The index $\tau$ denotes the time period relative to $t$ and is measured in months. $\tau$ runs from -6 to +6 and is normalized so that $\tau=0$ refers to the current month $t ; \tau<0$ refers to months prior to $t ; \tau>0$ refers to months after $t$. The range of $\tau$ determines the size of the event window. The indicator variable $\mu_{i}$ controls nonparametrically for employee fixed effects, such as level of education and gender. ${ }^{10}$ Because the resulting panel is unbalanced, the use of dummy variables is preferable

\footnotetext{
${ }^{10}$ In principle, one could also control for time- and award-specific effects. However, the relative nature of
} 
to fixed effects as controls for individual-specific effects (see, e.g., Greene [1997], p. 623). $X_{i t}$ is a vector of time-varying observable characteristics of the individual, in our case, the length of employment in the call center. $\alpha$ represents a constant, and $\xi_{i t}$ is a stochastic error term. To calculate standard errors, we cluster on the workgroup level per year. ${ }^{11}$ Alternative ways of adjusting standard errors are discussed below.

The key variables in this regression are the $W_{i \tau}$ indicator variables. $W_{i \tau}$ equals 1 for a person $i$ who receives a Gold Reward $\tau$ from $t$, and zero otherwise. As the Gold Reward is open to all employees in all periods, $W_{i \tau}$ captures all the relevant information because each employee is either a winner or a nonrecipient in each month. The vector $\pi_{\tau}$ are the parameters of interest in this equation and capture the period-specific effects on performance of winning a Gold Reward $\tau$ months from the current time period $t$ as compared to not winning an award, conditional on all covariates. By including an indicator variable for each period, the effect of being a winner is allowed to vary with $\tau$. For example, a coefficient $\pi_{+2}=0.5$ means that the performance of employees who won a Gold Reward two periods ago is 0.5 points higher than the one of nonrecipients. The time series of the coefficients $\pi_{\tau}$ around the event $(\tau=0)$ allows us to detect the causal effect of an award on performance. If the coefficients were significantly positive before the award was presented, there would be concerns about reverse causality. In case the performance of winners and nonrecipients is indistinguishable prior to an award for a large number of periods, we can be confident that our identifying assumption about the homogeneity of winners and nonrecipients holds.

As all individuals are winners or nonrecipients with respect to multiple awards, every

our performance measure already eliminates period-specific, exogenous shocks to performance. In addition, the Gold Rewards in the individual months that we cover are identical, so there is no reason to expect independent award-specific effects.

${ }^{11}$ We do not have obvious problems with grouped errors as the unit of observation corresponds with the unit of variation, i.e., the award. However, clustering on workgroups accounts for possible correlations of ratings within teams. As team composition varies between years due to employee fluctuation, workgroupper-year clusters are used. This also increases the number of clusters, which improves inference due to the asymptotic properties of the clustering procedure (Kiefer 1980; White 1980). 
performance observation simultaneously helps to identify all 13 different $\pi_{\tau}$ from $\pi_{+6}$, the performance of winners relative to nonrecipients six months prior to an award, to $\pi_{-6}$, the performance of winners relative to nonrecipients six months after an award.

\subsection{The Performance of Winners and Nonrecipients}

Figure 2 shows the average-mean-corrected performance of winners and nonrecipients around the award. ${ }^{12}$

The figure suggests that the performance of winners and nonrecipients is indistinguishable prior to an award and that the performance of winners increases relative to nonrecipients in the period following the award.

This first impression is confirmed in a regression analysis that controls for further factors and accounts for potential serial correlation. Table 2 presents the results when estimating equation (1) for two different subsets of employees. The first model includes all id-months observations with clean event windows. This means that those id-month observations are included where at most one of the winner dummies, $W_{i \tau}$, equals one to eliminate confounding effects. Model 2 only includes the id-month observations of those employees that have received at least one Gold Reward. As the entire sample is now comprised of Gold Reward recipients, our identifying assumption holds per definition because winners and nonrecipients in this sample are homogeneous in their underlying unobservable characteristics. In case the results of model 2 are identical to those of model 1, we can further strengthen our identifying assumption that winners and nonrecipients - even those who never receive an

\footnotetext{
${ }^{12}$ The sample of nonrecipients used to calculate the mean-adjusted performance comprises the performance ratings of those nonrecipients that are in teams with at least one winner in the respective month $t$. Excluded are the performance ratings of those nonrecipients that win a Gold Reward within six months around $t$.
} 
Figure 2: Performance of Winners and Nonrecipients Prior to and After an Award (with 90 percent confidence intervals)

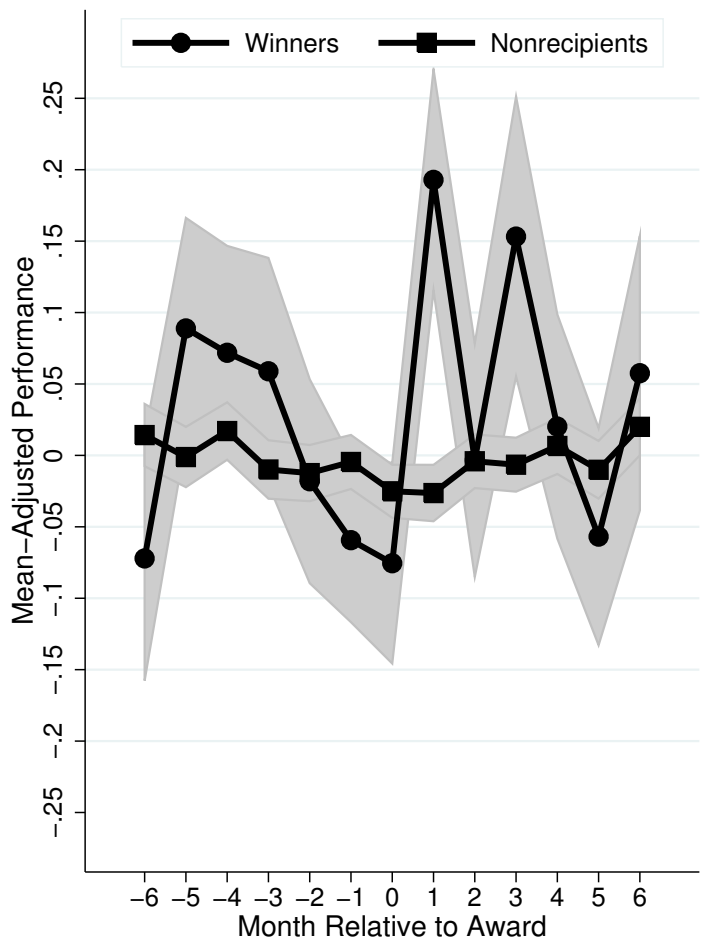

award-are homogeneous.

According to model 1 , the performance of winners is 0.24 or 7.4 percent higher than that of nonrecipients one month after the award. This increase is substantial, especially when taking into account the large number of Gold Reward winners at the call center and that we use performance in a job dimension that is not incentivized with the award as the dependent variable. Two months after the award, the difference in performance becomes insignificant. Consistent with our homogeneity assumption, we find that, in each of the six months prior to an award, recipients and nonrecipients have very similar performance ratings. Indeed, their performance ratings are statistically indistinguishable for this relatively large number 
Table 2: Impact of an Award on Performance (Six Months Before and After the Event)

\begin{tabular}{|c|c|c|}
\hline & Model 1 & Model 2 \\
\hline$\pi_{-6}$ & $\begin{array}{l}-0.055 \\
(-0.54)\end{array}$ & $\begin{array}{c}-0.069 \\
(-0.67)\end{array}$ \\
\hline$\pi_{-5}$ & $\begin{array}{r}0.123 \\
(1.37)\end{array}$ & $\begin{array}{r}0.117 \\
(1.31)\end{array}$ \\
\hline$\pi_{-4}$ & $\begin{array}{r}0.100 \\
(1.40)\end{array}$ & $\begin{array}{r}0.098 \\
(1.47)\end{array}$ \\
\hline$\pi_{-3}$ & $\begin{array}{c}0.076 \\
(0.76)\end{array}$ & $\begin{array}{r}0.080 \\
(0.84)\end{array}$ \\
\hline$\pi_{-2}$ & $\begin{array}{c}-0.013 \\
(-0.13)\end{array}$ & $\begin{array}{l}-0.008 \\
(-0.09)\end{array}$ \\
\hline$\pi_{-1}$ & $\begin{array}{c}-0.028 \\
(-0.39)\end{array}$ & $\begin{array}{c}-0.020 \\
(-0.29)\end{array}$ \\
\hline$\pi_{0}$ & $\begin{array}{c}-0.034 \\
(-0.51)\end{array}$ & $\begin{array}{l}-0.022 \\
(-0.33)\end{array}$ \\
\hline$\pi_{+1}$ & $\begin{array}{l}0.234^{* *} \\
(2.73)\end{array}$ & $\begin{array}{l}0.246^{* *} \\
(2.96)\end{array}$ \\
\hline$\pi_{+2}$ & $\begin{array}{r}0.015 \\
(0.12)\end{array}$ & $\begin{array}{r}0.035 \\
(0.29)\end{array}$ \\
\hline$\pi_{+3}$ & $\begin{array}{r}0.172 \\
(1.03)\end{array}$ & $\begin{array}{c}0.192 \\
(1.19)\end{array}$ \\
\hline$\pi_{+4}$ & $\begin{array}{l}-0.005 \\
(-0.05)\end{array}$ & $\begin{array}{r}0.017 \\
(0.17)\end{array}$ \\
\hline$\pi_{+5}$ & $\begin{array}{r}-0.050 \\
(-0.85)\end{array}$ & $\begin{array}{l}-0.022 \\
(-0.40)\end{array}$ \\
\hline$\pi_{+6}$ & $\begin{array}{r}0.005 \\
(0.05)\end{array}$ & $\begin{array}{r}0.032 \\
(0.28)\end{array}$ \\
\hline Tenure & $\begin{array}{l}0.013^{*} \\
(1.76)\end{array}$ & $\begin{array}{c}0.009 \\
(0.95)\end{array}$ \\
\hline Tenure $^{2}$ & $\begin{array}{c}-0.000 \\
(-0.98)\end{array}$ & $\begin{array}{c}-0.000 \\
(-0.81)\end{array}$ \\
\hline Constant & $\begin{array}{l}3.209^{* * *} \\
(37.29)\end{array}$ & $\begin{array}{l}3.228^{* * *} \\
(34.91)\end{array}$ \\
\hline $\begin{array}{l}\text { Observations } \\
R^{2}\end{array}$ & $\begin{array}{c}1202 \\
0.576\end{array}$ & $\begin{array}{c}667 \\
0.563\end{array}$ \\
\hline
\end{tabular}

$t$ statistics in parentheses

${ }^{*} p<.10,{ }^{* *} p<.05,{ }^{* * *} p<.01$ 
of periods. Overall, this finding lends credibility to the identifying assumption that the nonrecipients form a valid counterfactual for the winners. We do find, however, that the fixed effects of winners are, on average, higher than that of agents who never receive an award. While this implies that winners and nonrecipients are indeed not homogeneous with respect to their absolute core performance, they are homogeneous with respect to their core performance once these level effects have been taken into account because of the long time line of insignificant differences in performance prior to the award. ${ }^{13}$ Moreover, the results for model 2 closely resemble those of model 1, which further speaks against reverse causation. The control variable job tenure does not have a robust statistically significant effect on performance.

RESULT 1. Awards increase the performance of recipients as compared to nonrecipients subsequent to winning.

The same is true when using change in performance as the dependent variable. The winners' performances increase significantly more than the nonrecipients' performances between the month prior to the award and the month after. A closer look at performance in the individual performance dimensions shows that the overall result (i.e., the sizes of the coefficients and their significance levels) is clearly reflected in the Quality dimension and, to a lesser extent, in the dimension After Call Worktime. Performance also increases in all other performance dimensions, but the effect size and the specific lags that exhibit significant coefficients differ between dimensions and are not strong enough to have a significant

\footnotetext{
${ }^{13}$ In fact, this implies that employees that are productive in terms of the core performance are also the ones that engage in voluntary work behaviors and hence that there is no trade-off between the two kinds of activities. One might counter that awards are given to the productive types not because they actually engage in voluntary work behaviors, but because they collude with supervisors to gain additional compensation for their high performance. However, we can show that within the first five months at the company, employees who receive an award exhibit a higher core performance than those who never receive an award (Mann-Whitney test p-value: .07, one-sided). As employees at the beginning of their careers lack the necessary familiarity with their supervisors and the unwritten rules of the company, this supports the notion that it is in fact the high-performing individuals engaging in voluntary work behaviors rather than low-performing types.
} 
effect on the overall rating. However, these findings should be interpreted with care because only the aggregate rating is a useful measure of performance due to the trade-offs between the different dimensions.

\subsection{Development of Performance Over Time}

Analyzing the performance of winners and nonrecipients over time serves as a check for whether winners increase their performance not only relative to nonrecipients, but also relative to their own performance prior to winning. For the following nonparametric analysis, we use performance ratings that are corrected for individual-specific fixed effects and effect of tenure to make the analysis comparable to the regressions above. Comparing the performance of winners between the month of the award and the subsequent month (i.e., periods $\tau=0$ and $\tau=+1$ ), the one-sided t-test for paired samples suggests that performance is significantly higher $(\alpha=0.05$, p-value: .03) in the month after the award than in the month of the award. In contrast, the performance in the month prior to the award is not statistically different from the one in the month of the award. The average increase in performance between the month prior to the award and the month after the award is 0.16. There is no statistically significant difference in performance between any of these three months for nonrecipients (i.e., between the periods $\tau=-1, \tau=0$, and $\tau=+1$ ). Given that performance is relatively evaluated, that is, in comparison with the average performance in each month, which is driven by the large number of nonrecipients, this insignificance was to be expected. This implies that the observed increase in the relative performance measure for the winners may be driven by nonrecipients lowering their performance. This would be reflected in a deterioration of absolute performance. However, this is not the case. Absolute performance over the four years stays relatively stable. In particular, we do not detect a general trend in absolute performance or any individual performance dimension. In fact, there is a slight increase in absolute performance because quality increases somewhat. 
Hence, we can be sure that the observed increase in the ratings of the winners represents higher winner effort.

RESUlT 2. Receiving an award improves the performance of winners, whereas the performance of nonrecipients remains unaffected.

\subsection{Why Do Winners Work Harder?}

The observed increase in performance subsequent to winning an award can be attributed to induced feelings of organizational commitment. Akerlof and Kranton (2005), for instance, state that employees who identify with their company perform better and that employers can actively influence whether employees identify with the company. Specifically, initiation rites, such as award ceremonies, can be used to change self-perception. ${ }^{14}$ Our evidence, however, suggests that a Gold Reward does not cause a sustainable change in preferences (i.e., employee identity) because the effect is limited to the month subsequent to winning. Endocrinical studies suggest that hard-wired mechanisms can raise the performance of award winners. Increases in status caused, for instance, by a victory in a competition have been shown to be associated with a heightened level of testosterone. This in turn increases competitive behavior (Booth et al. 1989; Mazur and Booth 1998). Such effects can be interpreted as preference changes in economics, even though they affect behavior only for a short time after the occurrence of the change in status (i.e., for a number of hours after winning an award). Psychological evidence also suggests that a positive event, which induces a good mood, increases subsequent voluntary behavior when this is in line with the positive cognitions evoked by the event (Isen and Simmonds 1978). At the same time, receiving an award can also induce reciprocal actions (e.g., Fehr and Gächter [2000]

\footnotetext{
${ }^{14}$ According to Akerlof and Kranton (2005), cognitive dissonance (Festinger 1954) is the underlying psychological mechanism that drives this development of loyalty. Applying cognitive dissonance theory to awards implies that individuals, who have publicly accepted an award and thereby the rules and values of the organization, improve their views and valuation of the organization.
} 
or Kube, Maréchal, and Puppe [2008]). According to this theory, winners increase their efforts to reciprocate to the monetary bonus associated with winning the Gold Reward . However, it is highly unlikely that the entire effect we document is driven by the monetary bonus. First, the amount is small - only 3 percent of the average monthly salary of around CHF 4,500. Second, field studies have shown that the wage elasticity of workers' outputs ranges from roughly 0.15 to 0.44 (Fehr, Goette, and Zehnder 2008). Thus, the observed increase of 7.5 percent would require a wage increase between 15 to 50 percent. This corresponds to a bonus of between CHF 750 and 2,500, which is much higher than the actual amount of CHF 150. Another explanation for the observed increase in performance may be the increased visibility of the award winner in the month following the award. Recipients may feel a need to live up to the honor of having received an award for their voluntary work behaviors, and this may affect their core performances. This effect should be stronger for award winners whose core performance was below average prior to the award. The data allow us to test this hypothesis by separating the winners into two groups: those individuals who performed below average in $\tau=0$ and those who performed above average. Looking at how much performance increases between the month of the award and one month later, we find that, on average, the rating of low performers increases by 0.58 , whereas the performance of high performers decreases by 0.17 . The one-sample t-test indicates that both coefficients are highly significantly different from zero. This differential impact of winning an award supports the notion that the increase in performance is caused by social pressure or the winners wanting to live up to the award with respect to core performance. At the same time, the differentiated effect renders it highly unlikely that reciprocity or organizational commitment causes the increase because this should apply to under- and over-performing winners in the same manner. However, the differentiated effect could also be caused by mean reversion. Individuals who achieve a very good rating likely 
had extreme positive draws from the process generating their output. Their next draws are unlikely to meet or exceed prior realizations, causing their individual performance to revert to the population mean. Therefore, we use a longer time horizon to classify individuals as high- or low-performing. Specifically, we look at $\tau=+2, \tau=+1$, and $\tau=0$. Individuals that perform worse than average in two or three of those periods are classified as low performers. Low-performing winners increase their rating by 0.29 (which is significantly greater than zero at the 1 percent level), while the rating of high-performing winners changes by 0.03 (not significantly different from zero). ${ }^{15}$ Therefore, while there is some mean reversion going on, the differential impact of awards on the rating of high- and low-performing agents is robust.

Arguments rationalizing the observed effect without resorting to social motives unlikely play a role here. The award system is well established and the criteria clear to all employees. Therefore, handing out the award should not change the relevant information of the agents on the type of behavior and the required effort level to win. Further, the small bonus of CHF 150 unlikely changes the opportunity set of the agents or causes an income effect that could explain the result. Moreover, if there were any income effect, it would affect performance in the opposite direction and only strengthen the result that winning the award triggers employees to work harder. A Gold Reward has no impact on future promotion decisions, and employees know that. Strategic considerations about trying to win the award again also cannot explain the finding because this would not explain a further increase in performance above the level that was sufficient for winning. Further, if strategic considerations were the motive, the increase should last for more than one period. However, above all, any increase in core performance is by definition of the award criteria not linked

\footnotetext{
${ }^{15}$ The average rating of high performers in the month when they win an award is 3.52 (std. dev. 0.32), which suggests that the performance of high performers is not bounded from above, and they have the scope to increase their performance the same as low performers.
} 
to a higher chance of winning another Gold Reward because these reward activities are not captured in the core rating.

We can also rule out that the effect is caused by award winners focusing on those activities that lead to the award at the expense of core performance prior to winning. If the argument were true, the observed increase in performance after the award would only represent a return to the normal level of core performance, and winners and nonrecipients would not be homogeneous despite the similarity of their performance prior to the award. While such an effect could be imagined if one only looked at the three months prior to an award - the maximum time span that an activity eligible for winning lasts - the long time series of insignificant performance differences prior to an award renders the conjecture invalid. In addition, the difference in performance after an award should then also be sustained for more than one month.

Regarding the size of the effect, it is worth observing that the sizes of the documented effects only present a lower bound due to three reasons specific to this study. First, the Gold Reward is low in the hierarchy of awards at the company, and one would expect to find even larger effects for the other awards. Second, awards at the company are presented for beneficial behaviors that are not represented in the company's core performance measure, which we use as the dependent variable. Thus, the estimated effect of awards on core performance presents only the spillover effect of the presumably larger effect on those behaviors that are rewarded. One standard objection to award systems is that they induce individuals to exert unproductive efforts to increase their chances of winning. Our result, however, provides evidence to the contrary, as we observe an increase in productive effort. Hence, even if there were some rent seeking going on, it does not come at the expense of productivity. Third, we only measure the impact of the award subsequent to being presented. However, the award system as such does have an incentive effect that, while it 
cannot be captured in this study, probably has a substantial impact on the performance of all employees as they work towards the award. In a field experiment, Neckermann and Kosfeld (2008) find that the introduction of an award system increases performance by about 10 percent. ${ }^{16}$

\subsection{Robustness}

The following section addresses a variety of issues concerning the reliability of our results.

As is the case with most, if not all, event studies, our disturbances exhibit serial correlation. However, this issue does not affect our results because we estimate robust standard errors. Specifically, we report the robust (Huber-White sandwich) estimates of variance that provide correct estimates for any type of correlation within the observations of each panel/group. Moreover, Bertrand, Duflo, and Mullainathan (2004) show that, if the intervention variable is not serially correlated, OLS standard errors are consistent, despite the positive serial correlation in the residuals. This holds in our study because the average correlation of the independent variable over time for each individual is close to zero. Serial correlation and heteroskedasticity are more extensively addressed, and additional tests are reported in Appendix C. As a further robustness check we used the two-way cluster approach (Cameron, Gelbach, and Miller 2006), which provides cluster-robust inference when there is two-way clustering that is non-nested. The two dimensions that we checked were id and month because one could image errors to be clustered for all observations of one individual and within one month. However, our results are robust to this test as Table 3 in the appendix shows.

We already established above that the direction of causality runs from award to performance by showing (1) that there is no significant difference between the performance of

\footnotetext{
${ }^{16}$ Receiving an award may also have other beneficial side effects that cannot be measured as part of this study. For example, one might conjecture that awards have an additional positive affect on the retention rates of the award winners.
} 
winners and nonrecipients prior to an award and (2) that the results of models 1 and 2 are basically identical. Nevertheless, we additionally tested whether current or lagged performance determines if a person receives a Gold Reward. As expected, there is no significant effect of these variables on the likelihood of receiving an award. Only the length of tenure and its squared term have a significant impact, which provides an additional rationale for including these variables in the regressions presented above. Third, the results are robust with respect to the inclusion and exclusion of employees depending on the number of Gold Rewards received. The results do not change with a variation in the event window size (we tested event windows ranging from plus/minus 3 to 12 months). In addition, the inclusion of time fixed effects has no effect on the results, which we expected because the relative rating already eliminates any impact of time-varying changes in the business environment. We can also confirm that our result is not driven by the large weight of 50 percent of Quality in the index. Using a different index that weights all performance dimensions equally leads to the same pattern of performance, both in terms of the size of coefficients as well as significance levels.

\section{Conclusion}

In general, the use of incentives is indispensable in principal-agent relationships within organizations. Advances in behavioral economics have recently addressed and presented models of a wide set of human motivations such as the desire for status and positive self-image. However, awards as incentive instruments tapping a number of such motives have so far been neglected in economics despite their widespread use in the corporate sector and elsewhere.

This study shows that receiving an award for uncontractible, voluntary work behaviors such as organizing team events or substituting for sick employees increases core perfor- 
mance - those efforts that are more immediately linked with business success by 7.5 percent when compared to nonrecipients. To our knowledge, this study is the first to empirically assess the change in behavior induced by the receipt of an award in a principal-agent relationship. This study is unique in that it analyzes performance in a complex work environment - a task that is characterized by many different job dimensions including quality. Specifically, we show in the field that social incentives have a sizeable and robust positive effect on employee performance. Moreover, rewards influence behavior after they have been received, that is, beyond the incentive effect normally considered as people work towards receiving the reward. This clearly contradicts the notion that awards only influence behavior due to their effect on future monetary income and that awards only reflect high ability and performance, but do not cause it. Hence, incentive theory neglects an important part of the value of rewards. Additionally, awards as social incentives have a positive spillover effect on dimensions of the job that they do not target.

Social incentives may turn out to be invaluable in incentivizing types of activities that are desirable for the company, but not contractible. The vague nature of awards, for instance, better corresponds to the vague nature of activities such as helping colleagues or sharing knowledge. Therefore, employees may perceive social incentives to be a more adequate reward for these kinds of activities than monetary bonuses that put a clear dollar value on the exerted effort. Thereby, awards are less likely to reduce intrinsic motivation (see, e.g., Frey [1997]; Bénabou and Tirole [2003] on the crowding out of motivation). At the same time, multitasking problems may less likely occur. Moreover, social rewards may have a positive impact on the work climate and the shared beliefs about appropriate kinds of behavior. There is much scope for future research. One relevant question concerns the optimal number of awards and award categories. Additionally, a deeper understanding of all channels through which awards affect performance might improve our understanding of 
incentive provision in principal-agent relationships.

\section{Appendix}

\section{A. Awards at the Company}

\section{A.1. The Thank You Reward}

The Thank You reward is exchanged between colleagues. Whenever an employee chooses a colleague for a Thank You reward, the recipient immediately receives a notification per email and a letter is sent to her home address. Once a month, the three employees with the highest number of Thank You rewards receive gifts (if two employees have the same number of awards, a lottery decides). The first prize is dinner for two (value CHF 200); the second prize is travelers' checks (value CHF 100); the third prize is two cinema tickets (value CHF 40).

\section{A.2. The Gold Reward}

The Gold Reward is presented for extraordinary, non-contractual performance with an impact on the output of the whole work group. Each employee can nominate a colleague for a Gold Reward. Approval is required by the group manager of the nominated employee. Each Gold Reward is accompanied by a certificate for the wall as well as a bonus between CHF 100 and CHF 250 ( $\$ 100$ and $\$ 250)$. The reward is presented by the call center manager in front of the other team members. Additionally, the names of the winners are published on the intranet and listed in the monthly company newsletter, and the winners receive a trophy, which has their names engraved on it. 


\section{A.3. The Platinum Reward}

The Platinum Reward is handed out (1) for exceptional efforts benefiting the whole department or (2) for extraordinary performance over an extended period of time. Moreover, the behavior of the winner must clearly represent the values of the organization. Special attention is given to actions that further cooperation and collaboration across departments. As is the case with a Gold Reward, colleagues nominate individuals for a Platinum Reward. Both the department head as well as the supra-departmental reward committee have to approve the nomination. The Platinum Reward is presented by the human resources manager and comes with a bonus of between CHF 300 and CHF 750 (\$300 and \$750) and a trophy. The names of the winners are published on the intranet, listed in the monthly company newsletter, and additionally mentioned at the yearly Christmas ceremony. The Platinum Reward is presented much less frequently than the Gold Reward. Between 2004 and 2007, it was awarded to only seven employees in the call center. In general, call center employees have little scope to affect the performance of the whole department or to establish and foster cooperation between the departments. Hence, they have only limited opportunities to qualify for a Platinum Reward.

\section{A.4. The President Reward}

The nomination and approval procedure for the President Reward is identical to the one described for the Platinum Reward. However, this award requires the CEO's approval. The President Reward requites efforts that have benefited the company as a whole. As only a few activities meet this requirement, there are only a few President Rewards each month. Examples of actions that qualify for the President Reward are process innovations that save costs or discoveries of major credit card frauds. The President Reward comes with a trophy and an amount between CHF 1,000 and CHF 2,000 (the amount is about the same 
in US\$). The names of the winners are published on the intranet, listed in the monthly company newsletter, and additionally announced at the yearly Christmas ceremony.

\section{A.5. The Employee of the Month}

Each month, a committee chooses one of the Platinum and President Reward winners of the previous month as the Employee of the Month (Gold Reward winners are also considered when there are too few Platinum and President Reward winners). The title is awarded to that Platinum or President Reward winner who made the most significant contribution, in particular, a contribution that affects the success of the organization as a whole. The nomination requires approval by the CEO, and the award is presented by the human resources manager, often together with the CEO. The award comes with the privilege of using a company mini Cooper (including gasoline) in the respective month and a trophy. Between 2004 and 2007, five call center agents were awarded this title. An email containing a picture of the winner notifies all employees of the new Employee of the Month. In addition, the CEO mentions all Employees of the Month winners and shows their pictures at the yearly Christmas celebration.

Gold, Platinum, and President Rewards can be won multiple times by each call center agent and can be awarded to multiple employees in the same month. There is only one Employee of the Month per month, and this title can be awarded to the same individual only once per calendar year.

\section{A.6. The Employee of the Year}

At the end of each year, the reward committee and the CEO choose an Employee of the Year from among the Employee of the Month winners. The title is awarded to that Employee of the Month whose contribution benefited the company the most. The title is awarded at the yearly Christmas ceremony and comes with a trophy as well as a week of paid vacation in a summer cottage for up to six people including a generous allowance. 


\section{B. Distribution of Gold Rewards}

Figure 3: Distribution of Gold Rewards per Employee

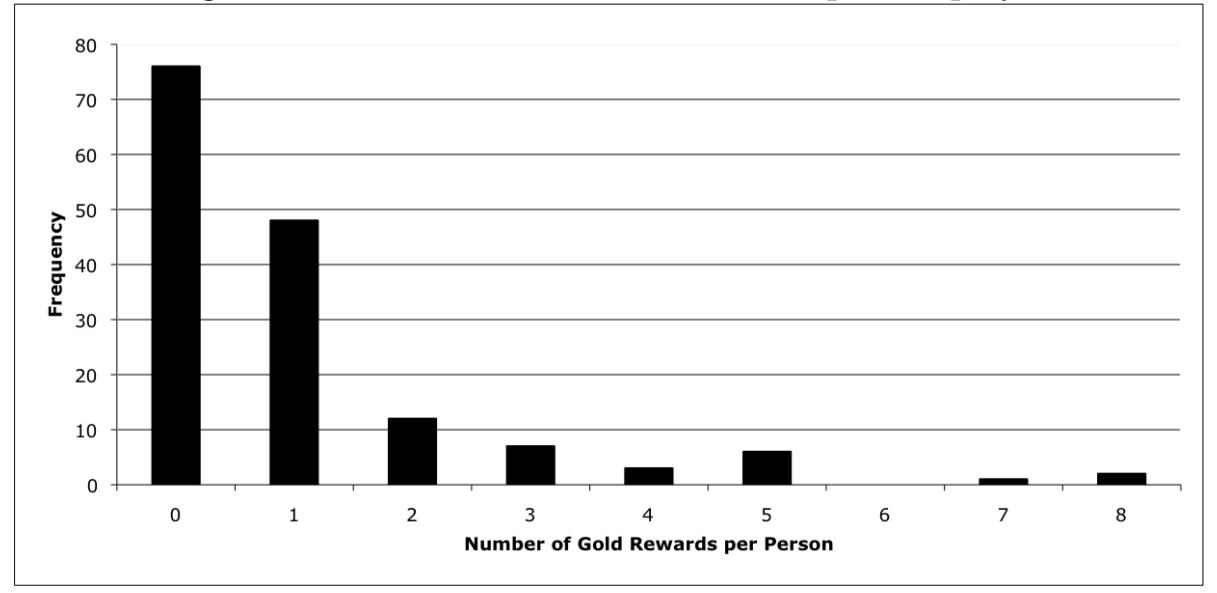

\section{Serial Correlation and Heteroskedasticity}

\section{C.1. Further Discussion}

With these kinds of event studies, one might worry about serial correlation and heteroskedasticity of the disturbances, despite the fact that this issue is rarely addressed. This would render the least squares estimator inefficient and even inconsistent if the regressors contain lagged dependent variables. Standard test statistics, such as the first-order autocorrelation coefficient of the residual (coefficient 0.125, significant at 1 percent level), obtained from regressing performance on individual characteristics (tenure and tenure ${ }^{2}$ ) and individual fixed effects, as well as the DW-statistic for panel data, do indeed suggest that disturbances are positively correlated. ${ }^{17}$ Serial correlation is also detected when using the Woolridge test for autocorrelation in panel data (Wooldridge 2002, pp. 282-283) (p-value: .05 for $H_{0}$ : no first-order autocorrelation). We also ran the modified Wald test for

\footnotetext{
${ }^{17}$ Second- and third-order autocorrelation coefficients are small (0.028 and 0.004) and insignificant.
} 
group-wise heteroskedasticity on the fixed effect model and found a highly significant test statistic. Therefore, we reject the null hypothesis that the panels in our model have common disturbance variances and that those disturbances are not correlated with the regressors. Hence, adjustments need to be made. If the goal were to estimate a model with complete dynamics, we needed to respecify the model because strong serial correlation is often an indication of omitting important explanatory variables or functional form misspecification. However, as this was not our goal, we had to find a way to carry out statistical inference in light of this positive correlation and potential heteroskedasticity (Wooldridge 2002, p. 402; Li and Hsiao 1998).

Bertrand, Duflo, and Mullainathan (2004) discuss serial correlation as a frequent problem, typically caused by the use of a fairly long time series, the positive serial correlation in the dependent variable, and the high degree of persistence of the intervention variable. They used Monte Carlo simulations to investigate how several estimation techniques helped to solve this serial correlation problem. They found that allowing for an unrestricted covariance structure over time within groups, with or without making the assumption that the error terms in all states follow the same process, worked well when the number of groups (i.e., units to which the intervention is applied, here: individuals) was greater than 50 . This is satisfied in our sample. In addition, we allow for an arbitrary variance-covariance matrix as we cluster on the team level. Specifically, clustering implies that the model is estimated by OLS applying the robust (Huber-White sandwich) estimates of variance. These variance estimates are robust in the sense of providing correct coverage rates to much more than panel-level heteroskedasticity (when only panel-level heteroskedasticity is present, a GLS estimation would be more efficient; otherwise, the GLS estimates are incorrect). In particular, they are robust to any type of correlation within the observations of each panel/group. Moreover, Bertrand, Duflo, and Mullainathan (2004) show that, if the intervention vari- 
able is not serially correlated, OLS standard errors are consistent, despite the positive serial correlation in the residuals. This is true in this study where the average correlation of the award variable over time for each individual is -.05 (correlation coefficients vary between -.31 and .47 with a mode and median of -.05$)$.

To further check the robustness of the reported standard errors, we recalculated them according to other methods suggested in the literature. In particular, we applied OLS with panel-corrected standard errors (PCSE) assuming heteroskedastic and contemporaneously correlated disturbances across panels (a method initially suggested by Beck and Katz [1995]). Analogous to the clustering approach presented above, applying OLS with PCSE errors provides consistent, but inefficient estimates in the face of heteroskedastic and correlated errors. In some sense, the PCSE approach is the opposite to the clustering approach because it allows for correlation among observations at the same period and in different panels, but only for certain types of within-panel correlation, here AR(1). The estimates that were calculated with the Prais-Winsten FGLS (Prais and Winsten 1954) assuming an $\mathrm{AR}(1)$ process in the disturbances, do not differ in any meaningful way from the ones presented above. The same holds, when we apply the Driscoll and Kraay standard errors for fixed effect models (Driscoll and Kraay 1998). These standard errors are robust to general forms of cross-sectional (spatial) and temporal dependence when the time dimension becomes large. Because this nonparametric technique of estimating standard errors places no restrictions on the limiting behavior of the number of panels, the size of the crosssectional dimension in finite samples does not constitute a constraint on feasibility - even if the number of panels is much larger than $T$. Hence, we are confident that the standard errors reported in the table are accurate. 


\section{C.2. Regressions With Two-Way Clustering}

Table 3: Models with One-Way (Team-Month Basis) and Two-Way (Id and Month) Clustering

\begin{tabular}{|c|c|c|c|c|}
\hline & $\begin{array}{l}\text { Model 1a } \\
\text { one-way }\end{array}$ & $\begin{array}{l}\text { Model 1b } \\
\text { two-way }\end{array}$ & $\begin{array}{l}\text { Model 2a } \\
\text { one-way }\end{array}$ & $\begin{array}{l}\text { Model 2b } \\
\text { two-way }\end{array}$ \\
\hline$\pi-6$ & $\begin{array}{l}-0.055 \\
(-0.54)\end{array}$ & $\begin{array}{l}-0.055 \\
(-0.53)\end{array}$ & $\begin{array}{c}-0.069 \\
(-0.67)\end{array}$ & $\begin{array}{c}-0.069 \\
(-0.62)\end{array}$ \\
\hline$\pi_{-5}$ & $\begin{array}{c}0.123 \\
(1.37)\end{array}$ & $\begin{array}{c}0.123 \\
(0.87)\end{array}$ & $\begin{array}{r}0.117 \\
(1.31)\end{array}$ & $\begin{array}{r}0.117 \\
(0.77)\end{array}$ \\
\hline$\pi_{-4}$ & $\begin{array}{c}0.100 \\
(1.40)\end{array}$ & $\begin{array}{c}0.100 \\
(1.25)\end{array}$ & $\begin{array}{c}0.098 \\
(1.47)\end{array}$ & $\begin{array}{c}0.098 \\
(1.18)\end{array}$ \\
\hline$\pi_{-3}$ & $\begin{array}{c}0.076 \\
(0.76)\end{array}$ & $\begin{array}{c}0.076 \\
(0.72)\end{array}$ & $\begin{array}{c}0.080 \\
(0.84)\end{array}$ & $\begin{array}{c}0.080 \\
(0.72)\end{array}$ \\
\hline$\pi_{-2}$ & $\begin{array}{c}-0.013 \\
(-0.13)\end{array}$ & $\begin{array}{l}-0.013 \\
(-0.12)\end{array}$ & $\begin{array}{l}-0.008 \\
(-0.09)\end{array}$ & $\begin{array}{l}-0.008 \\
(-0.07)\end{array}$ \\
\hline$\pi_{-1}$ & $\begin{array}{c}-0.028 \\
(-0.39)\end{array}$ & $\begin{array}{l}-0.028 \\
(-0.31)\end{array}$ & $\begin{array}{l}-0.020 \\
(-0.29)\end{array}$ & $\begin{array}{l}-0.020 \\
(-0.21)\end{array}$ \\
\hline$\pi_{0}$ & $\begin{array}{c}-0.034 \\
(-0.51)\end{array}$ & $\begin{array}{c}-0.034 \\
(-0.37)\end{array}$ & $\begin{array}{l}-0.022 \\
(-0.33)\end{array}$ & $\begin{array}{l}-0.022 \\
(-0.22)\end{array}$ \\
\hline$\pi_{+1}$ & $\begin{array}{l}0.234^{* *} \\
(2.73)\end{array}$ & $\begin{array}{l}0.234^{* *} \\
(2.04)\end{array}$ & $\begin{array}{l}0.246^{* *} \\
(2.96)\end{array}$ & $\begin{array}{l}0.246^{* *} \\
(2.00)\end{array}$ \\
\hline$\pi_{+2}$ & $\begin{array}{c}0.015 \\
(0.12)\end{array}$ & $\begin{array}{c}0.015 \\
(0.12)\end{array}$ & $\begin{array}{c}0.035 \\
(0.29)\end{array}$ & $\begin{array}{c}0.035 \\
(0.25)\end{array}$ \\
\hline$\pi_{+3}$ & $\begin{array}{c}0.172 \\
(1.03)\end{array}$ & $\begin{array}{r}0.172 \\
(1.24)\end{array}$ & $\begin{array}{c}0.192 \\
(1.19)\end{array}$ & $\begin{array}{c}0.192 \\
(1.31)\end{array}$ \\
\hline$\pi_{+4}$ & $\begin{array}{l}-0.005 \\
(-0.05)\end{array}$ & $\begin{array}{l}-0.005 \\
(-0.06)\end{array}$ & $\begin{array}{r}0.017 \\
(0.17)\end{array}$ & $\begin{array}{r}0.017 \\
(0.16)\end{array}$ \\
\hline$\pi_{+5}$ & $\begin{array}{l}-0.050 \\
(-0.85)\end{array}$ & $\begin{array}{l}-0.050 \\
(-0.62)\end{array}$ & $\begin{array}{l}-0.022 \\
(-0.40)\end{array}$ & $\begin{array}{l}-0.022 \\
(-0.25)\end{array}$ \\
\hline$\pi_{+6}$ & $\begin{array}{c}0.005 \\
(0.05)\end{array}$ & $\begin{array}{c}0.005 \\
(0.05)\end{array}$ & $\begin{array}{c}0.033 \\
(0.28)\end{array}$ & $\begin{array}{c}0.033 \\
(0.29)\end{array}$ \\
\hline Tenure & $\begin{array}{l}0.013^{*} \\
(1.76)\end{array}$ & $\begin{array}{l}0.013^{*} \\
(1.83)\end{array}$ & $\begin{array}{c}0.009 \\
(0.95)\end{array}$ & $\begin{array}{c}0.009 \\
(0.82)\end{array}$ \\
\hline Tenure ${ }^{2}$ & $\begin{array}{l}-0.000 \\
(-0.98)\end{array}$ & $\begin{array}{l}-0.000 \\
(-1.02)\end{array}$ & $\begin{array}{l}-0.000 \\
(-0.81)\end{array}$ & $\begin{array}{l}-0.000 \\
(-0.62)\end{array}$ \\
\hline Constant & $\begin{array}{c}3.209^{* * *} \\
(37.29)\end{array}$ & $\begin{array}{l}3.209^{* * *} \\
(22.65)\end{array}$ & $\begin{array}{c}3.228^{* * *} \\
(34.91)\end{array}$ & $\begin{array}{l}3.228^{* * *} \\
(21.45)\end{array}$ \\
\hline $\begin{array}{l}\text { Observations } \\
R^{2}\end{array}$ & $\begin{array}{l}1202 \\
0.576\end{array}$ & & $\begin{array}{c}667 \\
0.563\end{array}$ & \\
\hline
\end{tabular}




\section{References}

Akerlof, George A., and Rachel E. Kranton, "Identity and the Economics of Organizations," Journal of Economic Perspectives, 19 (2005), 9-32.

Alchian, Armen A., and Harold Demsetz, "Production, Information Costs, and Economic Organization," American Economic Review, 62 (1972), 777-795.

Angrist, Joshua D., and Alan B. Krueger, "Empirical Strategies in Labor Economics," in Handbook of Labor Economics, Volume 3, Orley C. Ashenfelter and David Card, eds. (New York: Elsevier Science, 1999).

Auriol, Emmanuelle, and Régis Renault, "Status and Incentives," The RAND Journal of Economics, 39 (2008), 305-326.

Beck, Nathaniel, and Jonathan N. Katz, "What to Do (and Not to Do) with Time-Series Cross-Section Data," American Political Science Review, 89 (1995), 634-647.

Bénabou, Roland, and Jean Tirole, "Self-Confidence and Personal Motivation," Quarterly Journal of Economics, 117 (2002), 871-915.

—_, "Intrinsic and Extrinsic Motivation," Review of Economic Studies, 70 (2003), 489520.

Bertrand, Marianne, Esther Duflo, and Sendhil Mullainathan, "How Much Should we Trust Differences-in-Differences Estimates?" Quarterly Journal of Economics, 119 (2004), 249275.

Besley, Timothy, and Maitreesh Ghatak, "Status Incentives," American Economic Review, 98 (2008), 206-211. 
Booth, Alan, Greg Shelley, Allan Mazur, Gerry Tharp, and Roger Kittok, "Testosterone, and Winning and Losing in Human Competition," Hormones And Behavior, 23 (1989), $556-571$.

Brennan, Geoffrey, and Philip Pettit, The Economy of Esteem: An Essay on Civil and Political Society (New York: Oxford University Press, 2004).

Cameron, Adrian C., Jonah B. Gelbach, and Douglas L. Miller, "Robust Inference with Multi-Way Clustering," NBER Working Paper No. 327, National Bureau of Economic Research, 2006.

Driscoll, John C., and Aart C. Kraay, "Consistent Covariance Matrix Estimation with Spatially Dependent Panel Data," The Review of Economics and Statistics, 80 (1998), $549-560$.

Dur, Robert, "Gift Exchange in the Workplace: Money or Attention?" IZA Discussion Paper No. 3839, Institute for the Study of Labor, Bonn, Germany 2008.

Fehr, Ernst, and Simon Gächter, "Fairness and Retaliation: The Economics of Reciprocity," Journal of Economic Perspectives, 14 (2000), 159-181.

Fehr, Ernst, Lorenz Goette, and Christian Zehnder, "The Behavioral Economics of the Labor Market: Central Findings and Their Policy Implications," IEW Working Paper No. 394, Institute for Empirical Research in Economics, University of Zurich, Switzerland, 2008.

Festinger, Leon, “A Theory of Social Comparison Processes," Human Relations, 7 (1954), $117-140$.

Frey, Bruno S., Not Just for the Money: An Economic Theory of Personal Motivation (Cheltenham, UK: Edward Elgar Publishing, 1997). 
—_, "Knight Fever: Towards an Economics of Awards," IEW Working Paper No. 239, Institute for Empirical Research in Economics, University of Zurich, Switzerland, 2005.

Gavrila, Caius, Jonathan P. Caulkins, Gustav Feichtinger, Gernot Tragler, and Richard F. Hartl, "Managing the Reputation of an Award to Motivate Performance," Mathematical Methods of Operations Research, 61 (2005), 1-22.

Greene, William H., Econometric Analysis, 3rd ed. (Upper Saddle River, NJ: Prentice Hall, 1997).

Greenstone, Michael, and Enrico Moretti, "Bidding for Industrial Plants: Does Winning a "Million" Dollar Plant Increase Welfare?" NBER Working Paper No. 9844, National Bureau of Economic Research, 2004.

Hansen, William L., and Burton A. Weisbrod, "Toward a General Theory of Awards, or, Do Economists Need a Hall of Fame?" Journal of Political Economy, 80 (1972), 422-431.

Ichniowski, Casey, and Kathryn Shaw, "Beyond Incentive Pay: Insiders' Estimates of the Value of Complementary Human Resource Management Practices," Journal of Economic Perspectives, 17 (2003), 155-180.

Isen, Alice M., and Stanley F. Simmonds, "The Effect of Feeling Good on a Helping Task That is Incompatible with Good Mood," Social Psychology, 41 (1978), 346-349.

Jensen, Michael C., and William H. Meckling, "Theory of the Firm: Managerial Behavior, Agency Costs and Ownership Structure," Journal of Financial Economics, 3 (1976), 305-360.

Kiefer, Nicholas M., "Estimation of Fixed Effect Models for Time Series of Cross-Sections with Arbitrary Intertemporal Covariance," Journal of Econometrics, 14 (1980), 195-202. 
Kube, Sebastian, Michel A. Maréchal, and Clemens Puppe, "The Currency of Reciprocity Gift-Exchange in the Workplace," Working Paper No. 377, Institute for Empirical Research in Economics, University of Zurich, Switzerland, 2008.

Li, Qi, and Cheng Hsiao, "Testing Serial Correlation in Semiparametric Panel Data Models," Journal of Econometrics, 87 (1998), 207-237.

MacKinlay, Archie C., "Event Studies in Economics and Finance," Journal of Economic Literature, 35 (1997), 13-39.

Malmendier, Ulrike, and Geoffrey Tate, "Superstar CEOs," NBER Working Paper No. 14140, National Bureau of Economic Research, 2008.

Markham, Steven E., K. D. Scott, and Gail H. McKee, "Recognizing Good Attendance: A Longitudinal, Quasi-Experimental Field Study," Personnel Psychology, 55 (2002), 639-660.

Mazur, Allan, and Alan Booth, "Testosterone and Dominance in Men," Behavioral and Brain Sciences, 21 (1998), 353-363.

Murphy, Kevin R., and Jeanette N. Cleveland, Understanding Performance Appraisal. Social, Organizational and Goal-Based Perspectives (Thousand Oaks, USA: Sage Publications, 1995).

Neckermann, Susanne, and Bruno S. Frey, "Awards as Incentives," IEW Working Paper No. 334, Institute for Empirical Research in Economics, University of Zurich, Switzerland, 2008.

Neckermann, Susanne, and Michael Kosfeld, "Working for Nothing? The Effect of NonMaterial Awards on Employee Performance," Mimeo, Institute for Empirical Research in Economics, University of Zurich, Switzerland, 2008. 
Nelson, Bob, 1001 Ways to Reward Employees, 2nd ed. (New York: Workman Publishing Company, 2005).

Peters, Florian S., and Andreas F. Wagner, "The Executive Turnover Risk Premium," Swiss Finance Institute Research Paper No. 08-11, Swiss Finance Institute, Zurich, Switzerland, 2008.

Prais, Sigbert J., and Christopher B. Winsten, "Trend Estimators and Serial Correlation," Discussion Paper No. 383, Cowles Commission for Research in Economics, 1954.

Suvorov, Anton, and Jeroen van de Ven, "Discretionary Bonuses as a Feedback Mechanism," Working Paper No. 0088, Center for Economic and Financial Research, Moscow, Russia , 2006.

White, Halbert, "A Heteroskedasticity-Consistent Covariance Matrix Estimator and a Direct Test for Heteroskedasticity," Econometrica, 48 (1980), 817-838.

Wooldridge, Jeffrey M., Econometric Analysis of Cross Section and Panel Data (Cambridge, MA: MIT Press, 2002).

—, Introductory Econometrics: A Modern Approach, 2nd ed. (Mason, OH: Thomson South-Western, 2002).

Yariv, Eliezer, "“Mum Effects": Principals' Reluctance to Submit Negative Feedback," Journal of Managerial Psychology, 21 (2006), 533-546. 


\section{CESifo Working Paper Series}

for full list see www.cesifo-group.org/wp

(address: Poschingerstr. 5, 81679 Munich, Germany, office@cesifo.de)

2593 Paolo M. Panteghini, On the Equivalence between Labor and Consumption Taxation, March 2009

2594 Bruno S. Frey, Economists in the PITS?, March 2009

2595 Natalie Chen and Dennis Novy, International Trade Integration: A Disaggregated Approach, March 2009

2596 Frédérique Bec and Christian Gollier, Term Structure and Cyclicity of Value-at-Risk: Consequences for the Solvency Capital Requirement, March 2009

2597 Carsten Eckel, International Trade and Retailing, March 2009

2598 Gianni De Nicolò and Iryna Ivaschenko, Global Liquidity, Risk Premiums and Growth Opportunities, March 2009

2599 Jay Pil Choi and Heiko Gerlach, International Antitrust Enforcement and Multi-Market Contact, March 2009

2600 Massimo Bordignon and Guido Tabellini, Moderating Political Extremism: Single Round vs Runoff Elections under Plurality Rule, April 2009

2601 Ana B. Ania and Andreas Wagener, The Open Method of Coordination (OMC) as an Evolutionary Learning Process, April 2009

2602 Simon Gächter, Daniele Nosenzo, Elke Renner and Martin Sefton, Sequential versus Simultaneous Contributions to Public Goods: Experimental Evidence, April 2009

2603 Philippe Jehiel and Andrew Lilico, Smoking Today and Stopping Tomorrow: A Limited Foresight Perspective, April 2009

2604 Andreas Knabe, Steffen Rätzel, Ronnie Schöb and Joachim Weimann, Dissatisfied with Life, but Having a Good Day: Time-Use and Well-Being of the Unemployed, April 2009

2605 David Bartolini and Raffaella Santolini, Fiscal Rules and the Opportunistic Behaviour of the Incumbent Politician: Evidence from Italian Municipalities, April 2009

2606 Erkki Koskela and Jan König, Can Profit Sharing Lower Flexible Outsourcing? A Note, April 2009

2607 Michel Beine, Frédéric Docquier and Çağlar Özden, Diasporas, April 2009

2608 Gerd Ronning and Hans Schneeweiss, Panel Regression with Random Noise, April 2009 
2609 Adam S. Booij, Bernard M.S. van Praag and Gijs van de Kuilen, A Parametric Analysis of Prospect Theory's Functionals for the General Population, April 2009

2610 Jeffrey R. Brown, Julia Lynn Coronado and Don Fullerton, Is Social Security Part of the Social Safety Net?, April 2009

2611 Ali Bayar and Bram Smeets, Economic, Political and Institutional Determinants of Budget Deficits in the European Union, April 2009

2612 Balázs Égert, The Impact of Monetary and Commodity Fundamentals, Macro News and Central Bank Communication on the Exchange Rate: Evidence from South Africa, April 2009

2613 Michael Melvin, Christian Saborowski, Michael Sager and Mark P. Taylor, Bank of England Interest Rate Announcements and the Foreign Exchange Market, April 2009

2614 Marie-Louise Leroux, Pierre Pestieau and Gregory Ponthiere, Should we Subsidize Longevity?, April 2009

2615 Ronald MacDonald, Lukas Menkhoff and Rafael R. Rebitzky, Exchange Rate Forecasters' Performance: Evidence of Skill?, April 2009

2616 Frederick van der Ploeg and Steven Poelhekke, The Volatility Curse: Revisiting the Paradox of Plenty, April 2009

2617 Axel Dreher, Peter Nunnenkamp, Hannes Öhler and Johannes Weisser, Acting Autonomously or Mimicking the State and Peers? A Panel Tobit Analysis of Financial Dependence and Aid Allocation by Swiss NGOs, April 2009

2618 Guglielmo Maria Caporale, Roman Matousek and Chris Stewart, Rating Assignments: Lessons from International Banks, April 2009

2619 Paul Belleflamme and Martin Peitz, Asymmetric Information and Overinvestment in Quality, April 2009

2620 Thomas Dohmen, Armin Falk, David Huffman and Uwe Sunde, Are Risk Aversion and Impatience Related to Cognitive Ability?, April 2009

2621 Yin-Wong Cheung and Xingwang Qian, The Empirics of China's Outward Direct Investment, April 2009

2622 Frédérique Bec and Christian Gollier, Assets Returns Volatility and Investment Horizon: The French Case, April 2009

2623 Ronnie Schöb and Marcel Thum, Asymmetric Information Renders Minimum Wages Less Harmful, April 2009

2624 Martin Ruf and Alfons J. Weichenrieder, The Taxation of Passive Foreign Investment Lessons from German Experience, April 2009 
2625 Yao Li, Borders and Distance in Knowledge Spillovers: Dying over Time or Dying with Age? - Evidence from Patent Citations, April 2009

2626 Jim Malley and Ulrich Woitek, Technology Shocks and Aggregate Fluctuations in an Estimated Hybrid RBC Model, April 2009

2627 Jin Cao and Gerhard Illing, Endogenous Systemic Liquidity Risk, April 2009

2628 Thiess Buettner and Bjoern Kauder, Revenue Forecasting Practices: Differences across Countries and Consequences for Forecasting Performance, April 2009

2629 Håkan Selin, The Rise in Female Employment and the Role of Tax Incentives - An Empirical Analysis of the Swedish Individual Tax Reform of 1971, April 2009

2630 Nick Johnstone and Ivan Hascic, Environmental Policy Design and the Fragmentation of International Markets for Innovation, April 2009

2631 Spiros Bougheas, Richard Kneller and Raymond Riezman, Optimal Education Policies and Comparative Advantage, April 2009

2632 Jay Pil Choi and Heiko Gerlach, Multi-Market Collusion with Demand Linkages and Antitrust Enforcement, April 2009

2633 Thor O. Thoresen, Income Mobility of Owners of Small Businesses when Boundaries between Occupations are Vague, April 2009

2634 Guido Schwerdt and Amelie C. Wuppermann, Is Traditional Teaching really all that Bad? A Within-Student Between-Subject Approach, April 2009

2635 Kurt R. Brekke, Luigi Siciliani and Odd Rune Straume, Hospital Competition and Quality with Regulated Prices, April 2009

2636 Peter Diamond, Taxes and Pensions, April 2009

2637 Shoshana Grossbard, How "Chicagoan” are Gary Becker's Economic Models of Marriage?, May 2009

2638 Roland Strausz, Regulatory Risk under Optimal Incentive Regulation, May 2009

2639 Holger Zemanek, Ansgar Belke and Gunther Schnabl, Current Account Imbalances and Structural Adjustment in the Euro Area: How to Rebalance Competitiveness, May 2009

2640 Harald Hau and Marcel Thum, Subprime Crisis and Board (In-)Competence: Private vs. Public Banks in Germany, May 2009

2641 Martin Halla, Mario Lackner and Friedrich G. Schneider, An Empirical Analysis of the Dynamics of the Welfare State: The Case of Benefit Morale, May 2009

2642 Balázs Égert, Infrastructure Investment in Network Industries: The Role of Incentive Regulation and Regulatory Independence, May 2009 
2643 Christian Gollier, Expected Net Present Value, Expected Net Future Value, and the Ramsey Rule, May 2009

2644 Sören Blomquist and Håkan Selin, Hourly Wage Rate and Taxable Labor Income Responsiveness to Changes in Marginal Tax Rates, May 2009

2645 Dominique Demougin, Oliver Fabel and Christian Thomann, Implicit vs. Explicit Incentives: Theory and a Case Study, May 2009

2646 Francesco C. Billari and Vincenzo Galasso, What Explains Fertility? Evidence from Italian Pension Reforms, May 2009

2647 Kjell Arne Brekke, Karen Evelyn Hauge, Jo Thori Lind and Karine Nyborg, Playing with the Good Guys - A Public Good Game with Endogenous Group Formation, May 2009

2648 Guglielmo Maria Caporale and Luis A. Gil-Alana, Multi-Factor Gegenbauer Processes and European Inflation Rates, May 2009

2649 Henning Bohn, A Static Model for Voting on Social Security, May 2009

2650 Markus Haavio and Kaisa Kotakorpi, The Political Economy of Sin Taxes, May 2009

2651 Augusto de la Torre, María Soledad Martínez Pería and Sergio L. Schmukler, Drivers and Obstacles to Banking SMEs: The Role of Competition and the Institutional Framework, May 2009

2652 Tobias Lindhe and Jan Södersten, Dividend Taxation, Share Repurchases and the Equity Trap, May 2009

2653 Assaf Razin and Edith Sand, Migration-Regime Liberalization and Social Security: Political-Economy Effect, May 2009

2654 Yin-Wong Cheung and Hiro Ito, A Cross-Country Empirical Analysis of International Reserves, May 2009

2655 Bart Cockx and Bruno Van der Linden, Flexicurity in Belgium. A Proposal Based on Economic Principles, May 2009

2656 Michael Melvin, Lukas Menkhoff and Maik Schmeling, Exchange Rate Management in Emerging Markets: Intervention via an Electronic Limit Order Book, May 2009

2657 Susanne Neckermann, Reto Cueni and Bruno S. Frey, What is an Award Worth? An Econometric Assessment of the Impact of Awards on Employee Performance, May 2009 